\title{
P1 Transdüksiyon Yöntemi ile Birden Fazla Gen Bakımından Mutant Olan Escherichia coli Suşlarının Elde Edilmesi
}

\author{
Esra DİBEK ${ }^{1}$, Merve SEZER KÜRKÇÜ ${ }^{2 *}$, Begüm HAZAR ÇİFTÇİ ${ }^{3}$, Bekir ÇÖL ${ }^{1}$ \\ ${ }^{1}$ Muğla Sitkı Koçman Üniversitesi, Fen Fakültesi, Biyoloji Bölümü, 48600 Muğla \\ ${ }^{2}$ Muğla Sıtkı Koçman Üniversitesi, Araştırma Laboratuvarları Merkezi, 48600 Muğla \\ ${ }^{3}$ Muğla Sitkı Koçman Üniversitesi, Fen Fakültesi, Kimya Bölümü, 48600 Muğla \\ (ORCID: 0000-0002-8110-5466)( ORCID: 0000-0003-0947-2912) \\ (ORCID: 0000-0001-6169-0091)( ORCID: 0000-0001-8997-4116)
}

\begin{abstract}
$\ddot{O} \mathbf{z}$
Bakterilerde gen fonksiyonlarının keşfedilmesi ve fenotipik çalışmalarının yapılabilmesi için mutant suşların oluşturulması gerekmektedir. Bazı durumlarda, birden fazla gen açısından mutant olan suşlar oluşturulmalıdır çünkü bazı spesifik aktiviteler birden fazla gen tarafından kodlanmaktadır. P1 fajı, Escherichia coli'de, ikili, üçlü veya çoklu mutantların oluşturulmasında başvurulan, genelleştirilmiş bir transdüksiyon fajıdır. Bu faj, gelişimi sırasında, E. coli kromozomunun parçalarını (her bir partikülde genomun yaklaşık \% 2'si olmak üzere), rastgele bir şekilde faj kafasına paketleyebilmektedir. E. coli DNA'sını içeren fajlar, içerdikleri DNA parçalarını, alıcı bakteri hücrelerine enjekte edebilmektedir. Verici ve alıcı DNA bölgeleri arasındaki benzerlik ve seçici bir belirteç yardımıyla, transdüktanlar'ın elde edilmesi mümkün olmaktadır. Transdüksiyon için tercihen, P1 fajının, virülan bir türevi (P1vir) kullanılmaktadır, çünkü bu form, bakterinin genomuna entegre olamamaktadır. Fajın bu özelliğinin kullanılmasıyla geliştirilen tekniklerden birisi, P1 transdüksiyon tekniği olarak adlandırılmaktadır. Rekombinasyon teknolojisinde kullanılan bu teknik, E. coli genomuna ait DNA parçalarının, farklı suşlar arasında taşınmasını sağlamaktadır. Bu çalışmada, optimize ettiğimiz P1 transdüksiyon metodolojisinin, deneysel akış ve yeterli detaylarla birlikte, Türk bilim camiasına, ana dilimizde sunulması amaçlanmıştır. Bunun için, KEIO koleksiyonundan elde edilen dört adet tekli gen mutantları kullanılmıştır. İlk olarak, kanamisin (Kan) duyarlı bir alıcı suş oluşturmak için, her bir mutant suştan, Kan gen kasetleri çıkarılmıştır. Kan ${ }^{\mathrm{R}}$ kasetlerine sahip diğer dört adet KEIO mutant suşu, donör suşlar olarak kullanılmış ve P1 fajı bu suşlar ile kültür edilerek, lizatlar elde edilmiştir. Bu lizatlar ve alıcı suşlar daha sonra, lizatlardaki fajların içerdikleri DNA parçalarını, alıcı suş genomuna entegre edebilmesi için, transdüksiyona tabii tutulmuştur. Kanamisin ile seleksiyon sonucu, yeni mutant suşlar olan ikili mutantlar elde edilmiştir. Sonuçta, isimleri $\Delta t \operatorname{sgAugpA,~} \Delta y h d T o m p A, \Delta u g p A m d t G$ ve $\Delta$ aroGmalF olan, dört adet ikili mutant oluşturulmuştur. Deneysel akıştaki ilgili protokoller ve sonuçlara ait detaylar sunulmuş ve tartışılmıştır.
\end{abstract}

Anahtar kelimeler: P1 faj, transdüksiyon, Escherichia coli, ikili mutant.

\section{P1 Transduction Method to Construct Escherichia coli Mutant Strains Lacking More Than One Gene}

\begin{abstract}
Assigning gene functions and performing phenotypic studies of the bacteria require the construction of specific mutants that at times should lack more than one gene due to the redundancy of particular gene activities. P1 phage is a generalized transducing phage that can be used in constructing double, triple or multiple mutants of Escherichia coli. This phage is able to mistakenly package random fragments of E. coli chromosome ( 2\% of the genome into each particle) into the phage head during phage development. The phages with $E$. coli DNA can inject that DNA into recipient cells. Given homology between donor and recipient, and a selectable marker, transductants can be obtained. For transduction, a virulent derivative of phage P1 is preferably used because this form cannot integrate into the bacterial genome. The virulent phage can only develop using the lytic mode of development and produces phage progeny upon lysis of the host cell. This technique is based on recombination
\end{abstract}

*Sorumlu yazar:mervesezer@mu.edu.tr

Geliş Tarihi: 08.07.2019, Kabul Tarihi: 05.12.2019 
technology, allowing the DNA fragments of the E. coli genome to be transported among the strains.In this study, we optimized the P1 transduction methodology, which we aim to present to the Turkish scientific community in the native language with the experimental flow and sufficient details. For this reason, a number of four single gene mutants obtained from the KEIO collection were used. First, kanamycine (Kan) gene cassettes were removed from each mutant strain to create a recipient strain that is kan sensitive. The other four KEIO mutant strains with Kan ${ }^{\mathrm{R}}$ cassettes were used as the donor strains and P1 phage were cultured with these strains and the lysates were obtained. These lysates and recipient strains were then transduced to integrate the DNA fragments of the lysates into the recipient strain genome. Upon selection with kanamycine, new mutant strains, double mutants are obtained. As a result, four double mutants namely $\Delta t s g A u g p A, \Delta y h d T o m p A, \Delta u g p A m d t G$ and $\triangle a r o G m a l F$ were obtained and the details pertaining to the protocols and results are presented and discussed.

Keywords: P1 phage, transduction, Escherichia coli, double mutant.

\section{Giriş}

Bakteriyofaj terimi, bakterileri enfekte eden virüsler için kullanılan genel bir terim olup, P1 bakteriyofaj1 moleküler mikrobiyoloji çalışmalarında en sık kullanılan fajlardan biridir. P1 bakteriyofajı, ilk olarak Luigi Bertani tarafından 1951 yılında izole edilmiştir [2]. P1 faj1 1lıman bir faj olup çift zincirli, doğrusal yapıda genoma sahiptir [11]. Genomunda cre-lox olarak adlandırılan, çok aktif bir bölgeye özgü, rekombinasyon sistemine sahiptir ve bu bölge DNA'daki belirli bir bölgede rekombinasyonu teşvik etmektedir. Bu bölgedeki rekombinasyon çok sık olduğundan, bölgenin her iki tarafindaki genetik belirteçlerin bağlantısız olduğu görülmektedir, bu da cre-lox bölgesinde sonlanan bir lineer haritanın ortaya çıkmasına neden olmaktadır [9]. P1 fajının tüm genom dizisi 2004 yılında Lobocka ve arkadaşları tarafindan yayınlanmıştır. Bu faj E.coli ve bazı bakteriler içerisinde lizogenik hayat döngüsünü geçirirken, faj genomu hücrede bir plazmid gibi kalarak ya da hücre genomuna entegre olarak replike olmaktadır [7]. Bakteriyofajlar sadece hücreleri enfekte etmek ve öldürmekle kalmaz, aynı zamanda transdüksiyon olarak adlandırılan bir süreçte bazen bakteriyel DNA'yı bir hücreden diğerine aktarır. İki tip transdüksiyon görülmektedir, bunlardan genel transdüksiyon olarak adlandırılan, bakteri DNA'sının herhangi bir bölümünün bir bakteriden diğerine aktarılmasını sağlarken, özel transdüksiyon olarak adlandırılan diğer transdüksiyon tipinde ise, belirli genlerin bir bakteriden diğerine aktarılması sağlanmaktadır [9].

Replikasyon sirasında, fajın hücre genomuna entegre olması ve replikasyon sirasinda gerçekleşen transdüksiyon, mikrobiyal genetik çalışmalarında kullanılmaktadır. Transdüksiyon, bir bakteri konakçı hücresinden gelen genlerin, bir bakteriyel virüsün (bakteriyofaj) genomuna dahil edildiği ve daha sonra bakteriyofaj başka bir enfeksiyon döngüsünü başlattığında başka bir konakçı bakteriye taşındığı genetik rekombinasyon sürecidir [3]. Salmonella'da genetik rekombinasyon çalışmaları sırasında Zinder ve Lederberg tarafından 1952 yılında keşfedilmiştir [13,14]. Yapılan çalışmalar sonucunda yaklaşık $100 \mathrm{~kb}$ büyüklüğünde DNA parçalarının bir bakteriden diğerine P1 bakteriyofajı ile aktarılabildiği gösterilmiştir [10].

1955 yılında Lennox ve arkadaşlarının yaptıkları çalışmalar ile de P1 fajının E. coli'de transdüksiyon gerçekleştirebildiği bildirilmiştir [6]. Bu çalışmalar ile birlikte özellikle E.coli türü üzerinde genetik çalışmalar yapan araştırmacılar tarafından bu teknik sıklıkla kullanılmaya başlanmıştır. Bakterilerin genetik yapısını değiştirmek, bakteriyel genlerin fonksiyonlarını bulmak için ve diğer birçok genetik deney için önemli bir moleküler biyolojik teknik olarak kullanılmıştır [10].

Transdüksiyonun terminolojisine göre, bakteriyel DNA'y1 toplayan faja, transdüksiyon partikülü, bu fajın çoğaldığı ve konakçı DNA'yı topladığı orijinal bakteriyel suş'a, verici (donör) suş, enfekte ettiği bakteri suşuna da alıcı (resipient) suş adı verilmektedir. Başka bir bakteriden transdüksiyonla DNA alan hücrelere de transdüktant denilmektedir [9]. Bu teknikte faj, ilk olarak, genomu aktarılacak DNA dizilerini içeren bir suş ile büyütülür ve P1 lizatları elde edilir. Ortaya çıkan faj lizatı da ikinci bir alıcı suşu enfekte etmek için kullanılır. Elde edilen lizat, faj DNA'sının yanı sıra, bakteriyel DNA da içermektedir ve alıcı suşun enzimleri tarafından katalize edilen genetik rekombinasyon ile alıcı genomuna bakteriyel DNA fragmentlerin eklenmesi gerçekleşmektedir [7]. Bu teknik ile çalışılırken, alıcı ve verici suşlar, $\mathrm{P} 1$ virüs lizatları ve lizatların hücreye tutunabilmeleri için özellikle gerekli olan $50 \mathrm{mM}$ kalsiyum klorür $\left(\mathrm{CaCl}_{2}\right)$ ve $20 \mathrm{mM}$ sodyum sitrat içeren seçici besiyerleri önemlidir. 
FLP (flippase) rekombinaz geni, FLP rekombinazı kodlamakta olup, FLP-FRT (flippaseflippase recognition target) rekombinasyonu bir organizmanın DNA'sının in vivo koşullarda kontrol edilmesini sağlayan ve moleküler genetik çalışmalarda kullanılan bir rekombinasyon teknolojisidir [12]. Bu teknolojide kullanılan bir plazmid de pCP20 plazmididir. pCP20 plazmidi 9,4 kb büyüklügünde olan bir plazmiddir. Bu plazmid Flp rekombinaz, kloramfenikol $\left(\mathrm{Cm}^{\mathrm{R}}\right)$ ve ampisilin $\left(\mathrm{Amp}^{\mathrm{R}}\right)$ direnç genlerini taşımakta olup, sıcaklığa duyarlı bir replikasyon orijini içerir (Şekil 1). Plazmiddeki kloramfenikol ve ampisilin direnç genleri, plazmidi içeren veya alan bakteri suşlarının seçilimi için kullanılmaktadır ve P1 transdüksiyon deneylerinde tercih edilmektedir [4]. pCP20 plazmidi yüksek sicakl1kta kendini replike etme özelliğini kaybetmektedir. Bu yüzden hücre içerisinde plazmidi yanlış zamanda kaybetmemek için çalışmalarda inkübasyon sıcaklıklarına özellikle dikkat edilmelidir.

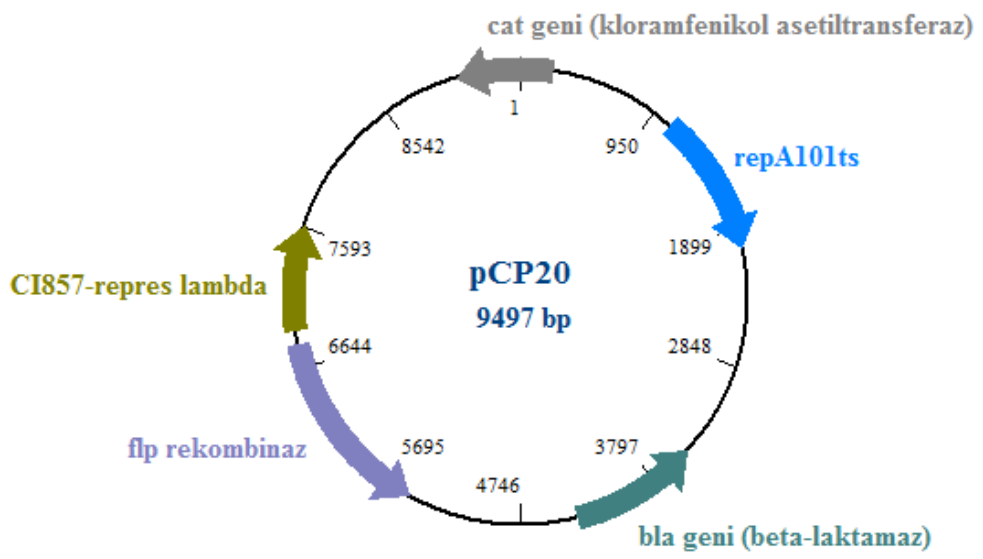

Şekil 1. pCP20 plazmidinin haritas1

Yapılan bu çalışmada kullanılan mutant suşlarındaki kanamisin gen kasetlerinin iki ucunda FRT dizileri yer almaktadır [1]. pCP20 plazmidinde yer alan FLP rekombinaz enzimi bu dizileri tanıyarak kanamisin gen kasedinin buradan çıkartılmasını ve hücrelerin kanamisin duyarlı olmalarını sağlamaktadır. Bu sayede bir genin genomdan çıkartılması, rekombinasyon ile o gen bölgesi yerine kanamisin gen kasedi sokulması ve seleksiyon ile gerçekleştirilebilmektedir [5]. Bu plazmidi taşıyan iki suştan biri olan E. coli BT340 (pCP20) suşu, plazmidin yeterli miktarda elde edilmesi ve izolasyonu için kullanılmıştır. E. coli BT340 suşunun genotipi şu şekildedir; F-, $\Delta\left(\arg F^{2}\right.$ lac $) 169$,

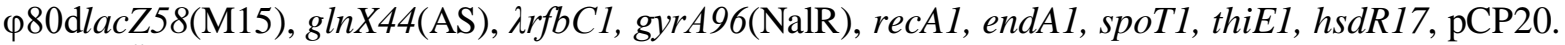

Öncelikle kanamisin kasetini çıkartmak için pCP20 plazmidinin söz konusu mutanta gönderilmesi gerekmektedir. P1 transdüksiyon deneyleri için, uygun P1 lizatının oluşturulması, transdüksiyon ve seleksiyon aşamaları gerçekleştirilmelidir. Bu çalışmada ülkemizdeki araştırmacıların ve öğrencilerin kullanımına sunmak üzere, P1 transdüksiyon deneylerinin akışı ve detayları, tarafımızca ilk defa oluşturulan ikili (double) mutantların elde edilmesi ile birlikte sunulmuştur.

\section{Materyal ve Metot}

Yapılan çalışmada temel olarak Silhavy ve arkadaşları tarafindan yayınlanan protokoller kullanılmıştır [8]. Ayrıca gerek duyulan yerlerde bazı optimizasyon çalışmaları gerçekleştirilerek protokol revize edilmiştir. P1 transdüksiyon tekniği kullanılarak bir genin nakavt edilebilmesi için pCP20 plazmidinin eldesi, kompetant hücre eldesi ve kanamisin gen kasedinin çıkartılması, lizat eldesi ve transdüksiyon çalışmaları gerçekleştirilmektedir. Bu çalışmada izlenilen deneysel akış şematik olarak özetlenmiştir (Şekil 2). 


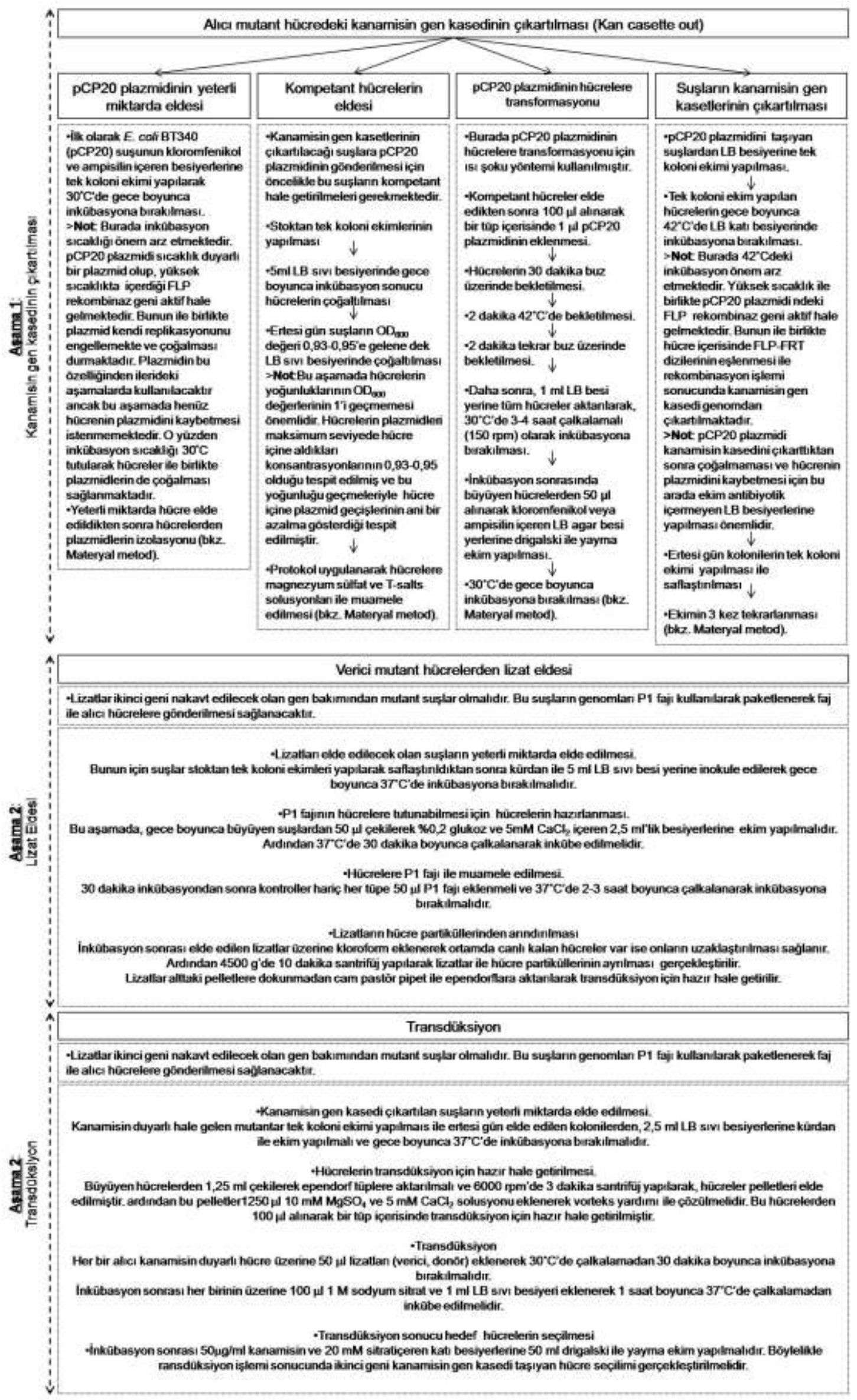

Şekil 2. Yapılan çalışmada izlenilen deneysel akışın şematik olarak gösterimi 


\subsection{Kullanılan $E$. coli suşları}

Yapılan bu çalışmada JW3417, JW0940, JW1040, JW3993 E.coli suşları transdüksiyon aşamasında kullanılmıştır. Bunun yanı sıra, JW3327, JW3225, JW3417, JW0737 E.coli suşları da lizatların eldesinde kullanılmıştır (Tablo 1). Bu suşlar laboratuvarımızda bulunan Keio koleksiyonundan temin edilmiştir (Baba vd. 2006).

Tablo 1. Çalışmada kullanılan E.coli suşları

\begin{tabular}{|c|c|c|}
\hline Suşlar & Genotip & Kaynakça \\
\hline E. coli $\mathrm{K}-12 \mathrm{BW} 25113$ & $\begin{array}{l}\text { lacI }^{q} r r n B_{T 14} \Delta l a c Z_{W J 16} \\
\text { AaraBdRAD } \\
\text { A }_{A H 33} \Delta r h a B A D_{L D 78}\end{array}$ & 14 \\
\hline JW3417 E. coli K-12 & lacI $^{q} \mathrm{rrnB}_{T 14} \Delta$ lac $Z_{W J 16}$ hsdR514 & 12 \\
\hline BW25113 $\Delta u g p A:: K a n^{R}$ & $\triangle a r a B A D_{A H 33} \Delta r h a B A D_{L D 78} \Delta u g p A \Omega \mathrm{Km}^{\mathrm{R}}$ & 12 \\
\hline JW0940 E. coli K-12 & lacI $I^{q} r r n B_{T 14} \Delta l a c Z_{W J I 6} h s d R 514$ & \\
\hline BW25113 $\triangle$ ompA::Kan & $\triangle a r a B A D_{A H 33} \Delta r h a B A D_{L D 78} \Delta o m p A \Omega \mathrm{Km}^{\mathrm{R}}$ & 12 \\
\hline JW1040 E. coli K-12 & lacI $^{q} r r n B_{T 14} \Delta l a c Z_{W J 16} h s d R 514$ & \\
\hline BW25113 $\Delta m d t G:: K a n$ & $\triangle a r a B A D_{A H 33} \Delta r h a B A D_{L D 78} \Delta m d t G \Omega \mathrm{Km}^{\mathrm{R}}$ & 12 \\
\hline JW3993 E. coliK-12 & lacI $^{q} r r n B_{T 14} \Delta \lambda a c Z_{W J 16} h s d R 514$ & 12 \\
\hline BW25113 $\Delta$ malF::Kan & $\triangle a r a B A D_{A H 33} \Delta r h a B A D_{L D 78} \Delta m a l F \Omega K^{\mathrm{R}}$ & 12 \\
\hline JW3327 E. coliK-12 & lacI $^{q} r r n B_{T 14} \Delta l a c Z_{W J 16} h s d R 514$ & \\
\hline BW25113 $\Delta t s g A:: K a n$ & $\triangle a r a B A D_{A H 33} \Delta r h a B A D_{L D 78} \Delta t s g A \Omega \mathrm{Km}^{\mathrm{R}}$ & 12 \\
\hline JW3417 E. coliK-12 & $\operatorname{lacI}^{q} \mathrm{rrnB}_{T 14} \Delta \operatorname{slac}_{\text {WJI6 }}$ hsdR514 & \\
\hline BW25113 $\Delta y h d T:: K a n$ & $\triangle a r a B A D_{A H 33} \Delta r h a B A D_{L D 78} \Delta y h d T \Omega \mathrm{Km}^{\mathrm{R}}$ & 12 \\
\hline JW0737E. coliK-12 & lacI $^{q} r r n B_{T 14} \Delta l a c Z_{W J 16} h s d R 514$ & 12 \\
\hline BW25113 AaroG::Kan & $\triangle a r a B A D_{A H 33} \Delta r h a B A D_{L D 78} \Delta a r o G \Omega \mathrm{Km}^{\mathrm{R}}$ & 12 \\
\hline
\end{tabular}

\section{2. pCP20 plazmidi ve izolasyonu}

İlk olarak E. coli BT340 (pCP20) suşu kloramfenikol ve ampisilin içeren besiyerlerine tek koloni ekimi yapılarak, $30^{\circ} \mathrm{C}$ 'de gece boyunca inkübasyona bırakılmıştır. $37^{\circ} \mathrm{C}$ 'de inkübasyona bırakılmamasının nedeni, pCP20 plazmidinin sıcaklığa duyarlı bir plazmid olmasıdır. Yüksek sıcaklıkta plazmitteki FLP rekombinaz geni aktif hale gelmekte ve plazmid kendi replikasyonunu engelleyebilmektedir. O yüzden plazmidi taşıyan suşun düşük sıcaklıkta yetiştirilerek, plazmidin de çoğalması sağlanmıştır. Daha sonra plazmid izolasyonu, GeneAll (Cat No:101-150) plazmid izolasyon kiti ile gerçekleştirilmiştir.

\section{3. pCP20 plazmidinin transformasyonu için kompetant hücrelerin eldesi}

Suşlar pCP20 plazmidinin transformasyonu için kompetant hale getirilirken, ilk olarak stoktan tek koloni ekimleri yapılmıştır. Ertesi gün tek düşen koloniden kürdan ile $5 \mathrm{ml} \mathrm{LB}$ sıvı besi yerine inokule edilmiştir. Gece boyunca $37^{\circ} \mathrm{C}$ 'de inkübasyona bırakıldıktan sonra, $500 \mu$ 'si $50 \mathrm{ml}$ LB besi yerine aktarılarak, $\mathrm{OD}_{600}$ değeri $0,93-0,95$ 'e gelene dek suşlar büyütülmüştür. $\mathrm{OD}_{600}$ değerinin 1 'i geçmemesine dikkat edilmiştir. Daha sonra büyütülen hücreler soğutmalı santrifüjde $4^{\circ} \mathrm{C}^{\prime}$ de $5000 \mathrm{rpm}$ hızında 5 dakika boyunca santrifüjlenerek çöktürülmüsstür. Pellet halinde elde edilen E.coli hücreleri 25 ml soğuk $0,1 \mathrm{M}$ magnezyum klorür $\left(\mathrm{MgCl}_{2}\right)$ ile çözülerek tekrardan çöktürülmüştür. Daha sonra elde edilen pellet E.coli hücreleri $12,5 \mathrm{ml} \mathrm{T}$-salts solusyonu ( $75 \mathrm{mM} \mathrm{CaCl}, 6 \mathrm{mM} \mathrm{MgCl} 2$ ) ile tekrardan yıkanarak, yaklaşık yarım saat boyunca buz üzerinde bekletildikten sonra, tekrar çöktürülmüştür. Ardından soğuk kompetant hücreler 2,5 ml T-salts solusyonu ile çözülerek transformasyon için hazır olacak şekilde elde edilmiştir. Elde edilen kompetant hücrelerden $100 \mu \mathrm{l}$ 'sine pCP20 plazmid transformasyonu "1s1 şoku ile transformasyon" protokolüne göre gerçekleştirilmiştir. Transformasyon sonras1 kloramfenikol $\left(\mathrm{Cm}^{\mathrm{R}}\right)$ ve ampisilin $\left(\mathrm{Amp}^{\mathrm{R}}\right)$ içeren LB-agar besiyerlerine $50 \mu \mathrm{l}$ hücre süspansiyonu, drigalski ile ekimi yapılmıştır. Ardından $30^{\circ} \mathrm{C}$ 'de gece boyunca inkübasyona bırakılmıştır. 


\subsection{Isı şoku ile transformasyon yöntemi}

Kompetant $E$. coli hücreleri elde edildikten sonra, bu hücrelere $1 \mu$ l plazmid eklenip, sırasıyla; 30 dakika buz üzerinde, 2 dakika $42^{\circ} \mathrm{C}$ 'de, 2 dakika tekrar buz üzerinde bekletilmiştir. Daha sonra, $1 \mathrm{ml} \mathrm{LB}$ besi yeri eklenerek, tüm hücreler, $30^{\circ} \mathrm{C}$ 'de 3-4 saat çalkalamalı $(150 \mathrm{rpm})$ olarak inkübasyona bırakılmıştır. İnkübasyon sonrasında büyüyen hücrelerden $50 \mu 1$ alınarak LB kloramfenikol veya ampisilin içeren LB agar besi yerlerine drigalski ile yayma ekim yapılmıştır.

\subsection{Hedef mutant suşlardan kanamisin kasedinin çıkartılması}

Hedef suşlara pCP20 plazmidinin transformasyonu sonucu elde edilen, plazmidi taşıyan suşlardan LB besiyerine tek koloni ekimi yapılmıştır. Her bir örnekten kontrol amaçlı 4 adet koloni seçilmiştir. Tek koloni ekim yapılan hücreler gece boyunca $42^{\circ} \mathrm{C}$ 'de inkübasyona bırakılmıştır. pCP20 plazmidinin, kanamisin kasedini çıkarıldıktan sonra çoğalmaması ve hücrenin plazmidini kaybetmesi için, burada ekim antibiyotik içermeyen LB besiyerlerine yapılmıştır. Ertesi gün kolonilerin saflaştırılması amacı ile tekrardan tek koloni ekimi yapılmıştır. Bu işlem 3 kez tekrarlanmıştır. Koloniler pürifiye edilmiştir.

Tek koloni seçilimleri gerçekleştirildikten sonra, kanamisin kasetlerini kaybeden örneklerden emin olunması amacı ile bir kontrol ekimi yapılmıştır. Burada elde edilen koloniler, kloramfenikol $\left(\mathrm{Cm}^{\mathrm{R}}\right)$, ampisilin $\left(\mathrm{Amp}^{\mathrm{R}}\right)$, kanamisin $\left(\mathrm{Kan}^{\mathrm{R}}\right)$ içeren ve antibiyotik içermeyen LB besiyerlerine ekilerek $37^{\circ} \mathrm{C}^{\prime}$ de gece boyunca inkübasyona bırakılmıştır. Kanamisin kasedi çıkartılan suşların antibiyotikli besiyerlerinde üreme göstermemesi $\left(\mathrm{Kan}^{\mathrm{s}}, \mathrm{Amp}^{\mathrm{s}}, \mathrm{Cm}^{\mathrm{s}}\right.$ olmasi), $\mathrm{LB}$ besiyerinde üremesi kontrol kriteri olarak kullanılarak, suşlardan kanamisin kasedinin çıkartıldığından ve plazmid içermediğinden emin olunmuştur.

\subsection{Lizat eldesi ve transdüksiyon}

Lizatları elde edilecek olan suşların stoktan tek koloni ekimleri yapılmıştır. Ertesi gün tek düşen koloniden kürdan ile $5 \mathrm{ml} \mathrm{LB}$ sıvı besi yerine inokule edilmiş̧ir. Gece boyunca $37^{\circ} \mathrm{C}$ 'de inkübasyona bırakılmıştır. Ertesi gün, gece boyunca büyüyen örneklerden $50 \mu 1$ çekilerek \% 0,2 glukoz ve $5 \mathrm{mM}$ $\mathrm{CaCl}_{2}$ içeren $2,5 \mathrm{ml}$ lik besiyerlerine ekim yapılmıştır. $37^{\circ} \mathrm{C}$ 'de 30 dakika boyunca çalkalanarak inkübasyona bırakılmışır. Bunun yanı sıra, lizat eklenmeyecek olan bir kontrol de inkübasyona eklenmiştir. 30 dakika inkübasyondan sonra, kontroller hariç, her tüpe $50 \mu \mathrm{P} 1$ faj1 eklenmiştir. Vorteksleme yapmadan hafifçe karıştırılmıştır. Ardından, tekrardan $37^{\circ} \mathrm{C}$ 'de $2-3$ saat boyunca çalkalanarak inkübasyona bırakılmıştır. İnkübasyon sonrası, lizat eklenen örnekler ile eklenmeyen kontrol arasında üreme farkı gözlemlenmiştir. Ardından steril cam pastör ile her bir örneğe 3 damla kloroform eklenerek vorteksleme yapılmıştır. 4500xg'de 10 dakika santrifüj yapılarak elde edilen lizatlar, alttaki pelletlere dokunmadan cam pastör pipet ile ependorflara aktarılmıştır. Böylelikle transdüksiyon için kullanılacak olan lizatlar elde edilmiştir.

Kanamisin kasedi çıkartılan suşlardan tek koloni ekimi yapılarak, elde edilen kolonilerden, 2,5 $\mathrm{ml}$ LB sıvı besiyerlerine kürdan ile ekim yapılmıştır ve gece boyunca $37^{\circ} \mathrm{C}$ 'de inkübasyona bırakılmıştır. Büyüyen hücrelerden 1,25 ml çekilerek ependorf tüplere aktarılmıştır. Tüplere aktarım kontaminasyonu önlemek için ince cam pastör pipet ile yapılmıştır. Ardından 6000 rpm'de 3 dakika santrifüj yapılarak, hücreler çöktürülmüştür. Pelletler üzerine $1250 \mu 10 \mathrm{mM} \mathrm{MgSO}$ ve $5 \mathrm{mM} \mathrm{CaCl}_{2}$ solusyonu eklenerek vorteks ile çözülmüştür. Hazırlanan kanamisin kasedi çıkartılan suşlardan $100 \mu \mathrm{l}$ tüplere konulmuştur. Lizat eklenecek olanlara yapılan eşleşmelere göre $50 \mu \mathrm{l}$ lizatları (verici, donör) eklenmiştir. $30^{\circ} \mathrm{C}$ 'de çalkalamada 30 dakika boyunca inkübasyona bırakılmıştır. İnkübasyon sonrası her birinin üzerine $100 \mu 11 \mathrm{M}$ sodyum sitrat eklenerek karıştırılmıştır. Ardından her birinin üzerine $1 \mathrm{ml}$ LB sıvı besiyeri eklenmiştir. 1 saat boyunca $37^{\circ} \mathrm{C}$ 'de çalkalamadan inkübasyona bırakılmıştır. İnkübasyon sonrası $50 \mu \mathrm{g} / \mathrm{ml}$ kanamisin ve $20 \mathrm{mM}$ sitrat içeren katı besiyerlerine $50 \mu \mathrm{l}$ drigalski ile yayma ekim yapılmıştır. Gece boyunca $37^{\circ} \mathrm{C}$ 'de inkübasyona bırakılmıştır. Elde edilen suşlardan saflaştırma yapılması için $50 \mu \mathrm{g} / \mathrm{ml}$ kanamisin ve $20 \mathrm{mM}$ sitrat içeren katı besiyerlerine tek koloni ekim yapılmıştır. 


\section{Bulgular ve Tartışma}

E. coli $\mathrm{BT} 340$ (pCP20) suşu kanamisin besiyerlerine tek koloni ekimi yapılarak $30^{\circ} \mathrm{C}$ 'de gece boyunca inkübasyona bırakılarak büyütülmüştür (Şekil 3).
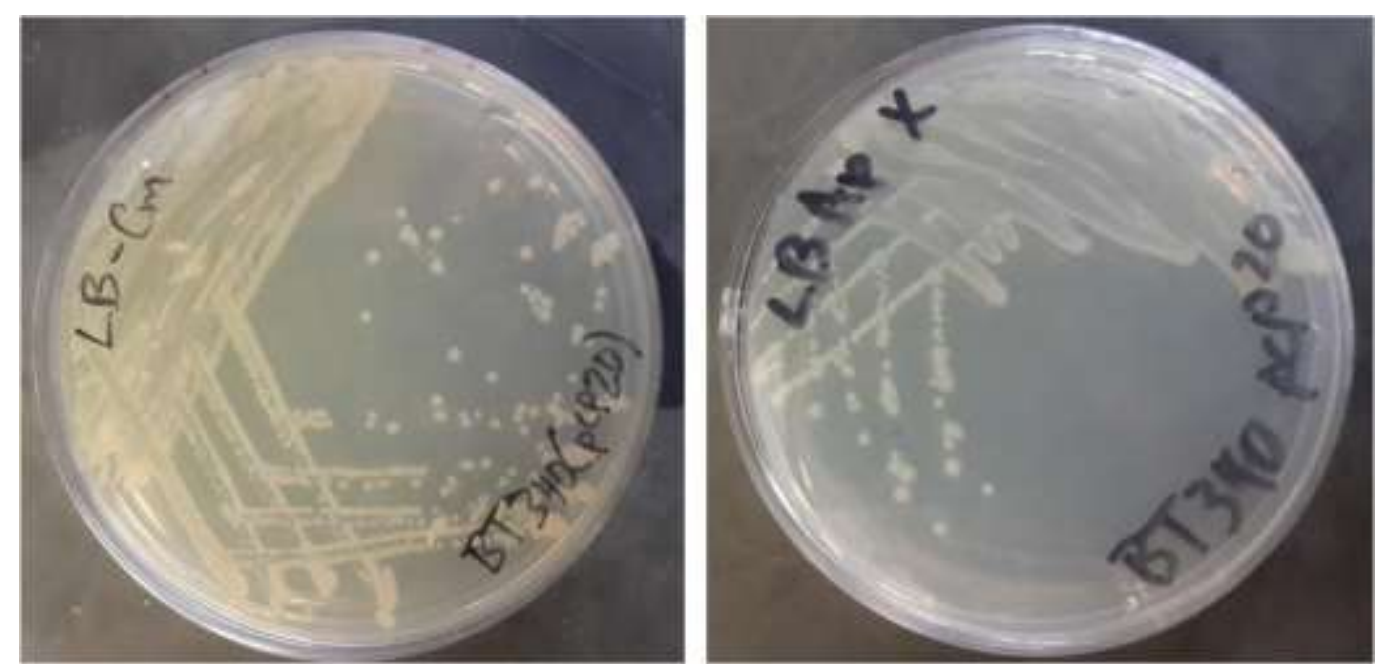

Şekil 3. pCP20 plazmidini içeren BT340 E. coli suşunun kloramfenikol ve ampisilin içeren LB agar besiyerlerinde tek koloni ekim görüntüleri

$\mathrm{Bu}$ şekilde yeterli miktarda pCP20 plazmidinin eldesi sağlanmıştır. Bu hücrelerden plazmid izolasyonu gene-all plazmid izolasyon kiti ile gerçekleştirilmiştir (Şekil 4).

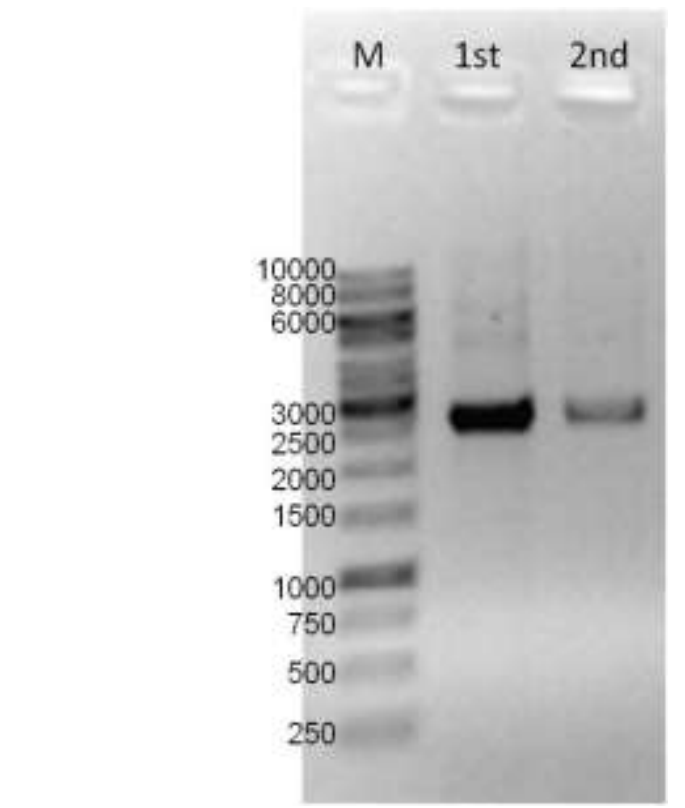

Şekil 4. pCP20 plazmidinin agaroz jel elektroforez analizi

Bu aşamada ilk olarak JW3417 E. coli K-12 BW25113 $\Delta u g p A \Omega \mathrm{Km}^{\mathrm{R}}$, JW0940 E. coli K-12 BW25113 $\Delta o m p A \Omega \mathrm{Km}^{\mathrm{R}}$, JW1040 E. coli $\mathrm{K}-12$ BW25113 $\Delta m d t G \Omega \mathrm{Km}^{\mathrm{R}}$ ve JW3993 E. coli $\mathrm{K}-12$ BW25113 $\Delta$ malF $\Omega \mathrm{Km}^{\mathrm{R}}$ suşları kompetant hale getirilerek, pCP20 plazmidinin 1s1 şoku yöntemi ile transformasyonu gerçekleştirilerek, pCP20 plazmidini taşıyan suşlar elde edilmiştir (Şekil 5). Ardından bu suşlar kanamisin gen kasetlerini kaybetmeleri için inkübasyon süreçlerinden geçirildikten sonra, kanamisin gen kasetlerini kaybetmiş olan JW3417 E. coli K-12 BW25113 $\Delta u g p A \Omega \mathrm{Km}^{\mathrm{S}}$, JW0940 E. coli $\mathrm{K}-12$ BW25113 $\Delta o m p A \Omega \mathrm{Km}^{\mathrm{S}}$, JW1040E. coli $\mathrm{K}-12$ BW25113 $\Delta m d t G \Omega \mathrm{Km}^{\mathrm{S}}$ ve JW3993 E. coli K12 BW25113 $\Delta$ malF $\Omega \mathrm{Km}^{\mathrm{S}}$ suşları elde edilmiştir (Tablo 2). 


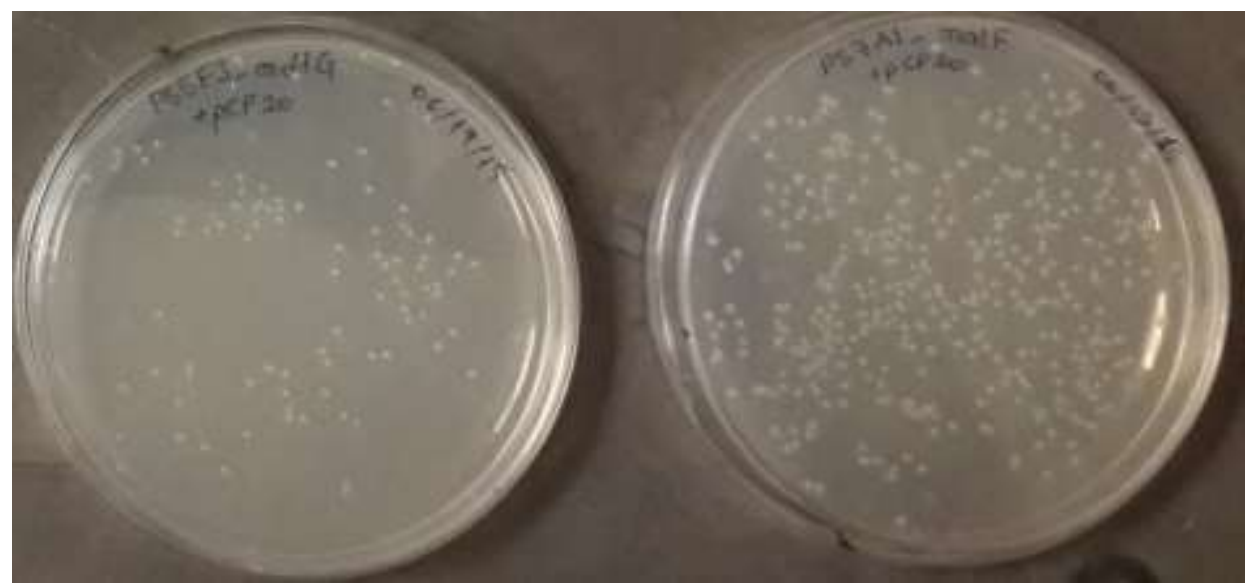

Şekil 5. Isı şoku yöntemi ile pCP20 plazmidinin transforme edilmesi sonucu elde edilen koloniler

Tablo 2. Çalışmada kanamisin gen kasetleri çıkartılarak elde edilen suşlar

\begin{tabular}{|c|c|c|}
\hline Suşlar & Genotip & Kaynakça \\
\hline JW3417 E. coli $\mathrm{K}-12$ & lacI $^{q} r r n B_{T I 4} \Delta l a c Z_{W J 16} h s d R 514$ & \\
\hline BW25113 $\Delta u g p A:: K a n^{S}$ & $\triangle a r a B A D_{A H 33} \Delta r h a B A D_{L D 78} \Delta u g p A \Omega \mathrm{Km}^{\mathrm{s}}$ & Bu çalışma \\
\hline JW0940 E. coli $\mathrm{K}-12$ & lacI $^{q} r r n B_{T 14} \Delta l a c Z_{W J 16} h s d R 514$ & \\
\hline BW25113 $\triangle o m p A:: K a n^{S}$ & $\triangle a r a B A D_{A H 33} \Delta r h a B A D_{L D 78} \Delta o m p A \Omega K \mathrm{~m}^{\mathrm{s}}$ & Bu çalışma \\
\hline JW1040 E. coli $\mathrm{K}-12$ & lacI $^{q} r r n B_{T 14} \Delta l a c Z_{W J 16}$ hsdR514 & \\
\hline $\mathrm{BW} 25113 \Delta m d t G:: K_{a n}{ }^{S}$ & $\triangle a r a B A D_{A H 33} \Delta r h a B A D_{L D 78} \Delta m d t G \Omega \mathrm{Km}^{\mathrm{s}}$ & Bu çalışma \\
\hline JW3993 E. coli $\mathrm{K}-12$ & lacI $^{q} \mathrm{rrnB}_{T 14} \Delta l a c Z_{W J 16} h s d R 514$ & Bu calısma \\
\hline BW25113 $\Delta m a l F:: K{ }^{S}$ & $\triangle a r a B A D_{A H 33} \Delta r h a B A D_{L D 78} \Delta m a l F \Omega \mathrm{Km}^{\mathrm{s}}$ & Bu çalışma \\
\hline
\end{tabular}

Hedeflenen genlerin genomdan çıkartılması için kullanılacak olan lizatlar elde edilmiştir. Bu

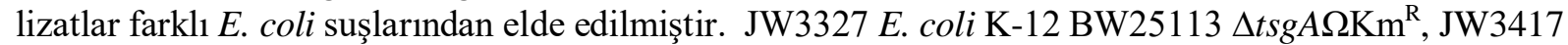
E. coli K-12 BW25113 $\Delta y h d T \Omega \mathrm{Km}^{\mathrm{R}}$, JW3417 E. coli K-12 BW25113 $\Delta$ ugpA $\Omega \mathrm{Km}^{\mathrm{R}}$, JW0737 E. coli K-12 BW25113 $\Delta$ aroG $\Omega \mathrm{Km}^{\mathrm{R}}$ suşlarına P1vir fajı ile muamele edilerek, bu suşların lizatları elde edilmiştir. Lizat elde edilmesi aşamasında, her bir verici suş için bir de P1 virüsü eklenmeden kontrol olarak büyümelerine bakılmıştır. P1vir fajı eklenen hücrelere ile eklenmeyenler arasındaki bulanıklılık farkı ile lizat oluşumları takip edilmiştir. Virüs eklenen suşlarda lizat oluşumu olduğundan ve bakteri hücreleri çoğalmadıklarından şeffaf bir görüntü gözlemlenirken virüs eklenmeyen bakteri hücreleri gelişmelerine devam ederek, besiyerinde gözle görülür bir yoğunluğa ulaşmışlardır (Şekil 6).

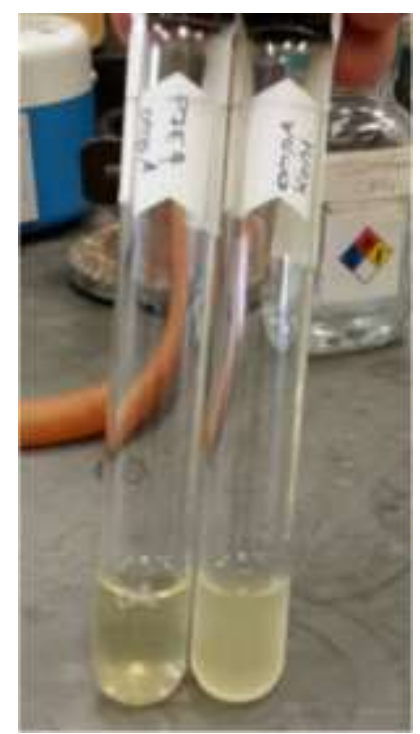

Şekil 6. Lizat eldesi sırasında virüs eklenen ve eklenmeyen suşların büyümelerinin ve lizat oluşumunun bakteri yoğunluğu ile takip edilmesi 
Ardından her biri kendisi için hedef belirlenen suş ile transdüksiyon aşamasından geçirilmiştir. JW3417 E. coli $\mathrm{K}-12$ BW25113 $\Delta u g p A \Omega \mathrm{Km}^{\mathrm{S}}$ suşuna $\Delta t s g A \Omega \mathrm{Km}^{\mathrm{R}}$ lizat1 ile JW0940 E. coli $\mathrm{K}-12$ BW25113 $\Delta o m p A \Omega \mathrm{Km}^{\mathrm{S}}$ suşuna $\Delta y h d T \Omega \mathrm{Km}^{\mathrm{R}}$ lizatı ile JW1040 E. coli $\mathrm{K}-12$ BW25113 $\Delta m d t G \Omega \mathrm{Km}^{\mathrm{S}}$ suşuna $\triangle u g p A \Omega \mathrm{Km}^{\mathrm{R}}$ lizat ile JW3993 E. coli $\mathrm{K}-12 \mathrm{BW} 25113 \Delta m a l F \Omega \mathrm{Km}^{\mathrm{S}}$ suşuna $\Delta a r o G \Omega \mathrm{Km}^{\mathrm{R}}$ lizatı ile muamele edilerek transdüksiyon gerçekleştirilmiştir.

Transdüksiyon sonucu E. coli $\mathrm{K}-12$ BW25113 $\mathrm{P}_{1} t s g A\left(\operatorname{Kan}^{\mathrm{R}}\right) \rightarrow \Delta u g p A\left(\operatorname{Kan}^{\mathrm{S}}\right)$, E. coli $\mathrm{K}-12$ BW25113 $\mathrm{P}_{1} y h d T\left(\operatorname{Kan}^{\mathrm{R}}\right) \rightarrow \Delta o m p A\left(\operatorname{Kan}^{\mathrm{S}}\right)$, E. coli $\mathrm{K}-12$ BW25113 $\mathrm{P}_{1} u g p A\left(\operatorname{Kan}^{\mathrm{R}}\right) \rightarrow \Delta m d t G\left(\operatorname{Kan}^{\mathrm{S}}\right), E$. coli $\mathrm{K}-12$ BW25113 $\mathrm{P}_{1}$ aro $G\left(\operatorname{Kan}^{\mathrm{R}}\right) \rightarrow \Delta$ mal $F\left(\operatorname{Kan}^{\mathrm{S}}\right)$ suşları elde edilmiştir (Tablo 3). Elde edilen suşların besiyerindeki üremiş durumlarını gösteren görüntüler şekil 7'de verilmiştir.

Tablo 3. Çalışmada elde edilen iki gen bakımından noksan mutant suşlar

\begin{tabular}{|c|c|c|}
\hline Suşlar & Genotip & Kaynakça \\
\hline $\begin{array}{l}\text { E. coli } \mathrm{K}-12 \mathrm{BW} 25113 \\
\mathrm{P}_{1} t \operatorname{sgA}\left(\operatorname{Kan}^{R}\right) \rightarrow \Delta u g p A\left(\operatorname{Kan}^{S}\right)\end{array}$ & $\begin{array}{l}\text { lacI }^{q} r r n B_{T 14} \Delta l a c Z_{W J 16} h s d R 514 \\
\Delta a r a B A D_{A H 33} \Delta r h a B A D_{L D 78} \Delta t s g A \Omega \mathrm{Km}^{\mathrm{s}} \Delta u g p A \Omega \mathrm{Km}^{\mathrm{R}}\end{array}$ & Bu çalışma \\
\hline $\begin{array}{l}\text { E. coli } \mathrm{K}-12 \mathrm{BW} 25113 \\
\mathrm{P}_{1} y h d T\left(\operatorname{Kan}^{R}\right) \rightarrow \Delta o m p A\left(\operatorname{Kan}^{S}\right)\end{array}$ & $\begin{array}{l}\text { lacI }^{q} \mathrm{rrnB}_{T 14} \Delta l a c Z_{W J 16} \text { hsdR514 } \\
\triangle a r a B A D_{A H 33} \Delta r h a B A D_{L D 78} \\
\Delta y h d T \Omega \mathrm{Km}^{\mathrm{s}} \Delta o m p A \Omega \mathrm{Km}^{\mathrm{R}}\end{array}$ & Bu çalışma \\
\hline $\begin{array}{l}\text { E. coli } \mathrm{K}-12 \text { BW } 25113 \\
\mathrm{P}_{1} u g p A\left(\operatorname{Kan}^{R}\right) \rightarrow \Delta m d t G\left(\operatorname{Kan}^{S}\right)\end{array}$ & $\begin{array}{l}\text { lacI }^{q} r r n B_{T 14} \Delta l a c Z_{W J 16} h s d R 514 \\
\Delta a r a B A D_{A H 33} \Delta r h a B A D_{L D 78} \\
\text { AugpA } \Omega \mathrm{Km}^{\mathrm{s}} \Delta m d t G \Omega \mathrm{Km}^{\mathrm{R}}\end{array}$ & $\mathrm{Bu}$ çalışma \\
\hline $\begin{array}{l}\text { E. coli } \mathrm{K}-12 \mathrm{BW} 25113 \\
\mathrm{P}_{1} \operatorname{aroG}\left(\operatorname{Kan}^{R}\right) \rightarrow \Delta \operatorname{malF}\left(\operatorname{Kan}^{S}\right)\end{array}$ & $\begin{array}{l}\operatorname{lacl}^{q} \mathrm{rrnB}_{T 14} \Delta l a c Z_{W J 16} h s d R 514 \\
\Delta a r a B A D_{A H 33} \Delta r h a B A D_{L D 78} \Delta \operatorname{aro} \Omega \Omega \mathrm{Km}^{\mathrm{s}} \Delta m a l F \Omega \mathrm{Km}^{\mathrm{R}}\end{array}$ & Bu çalışma \\
\hline
\end{tabular}

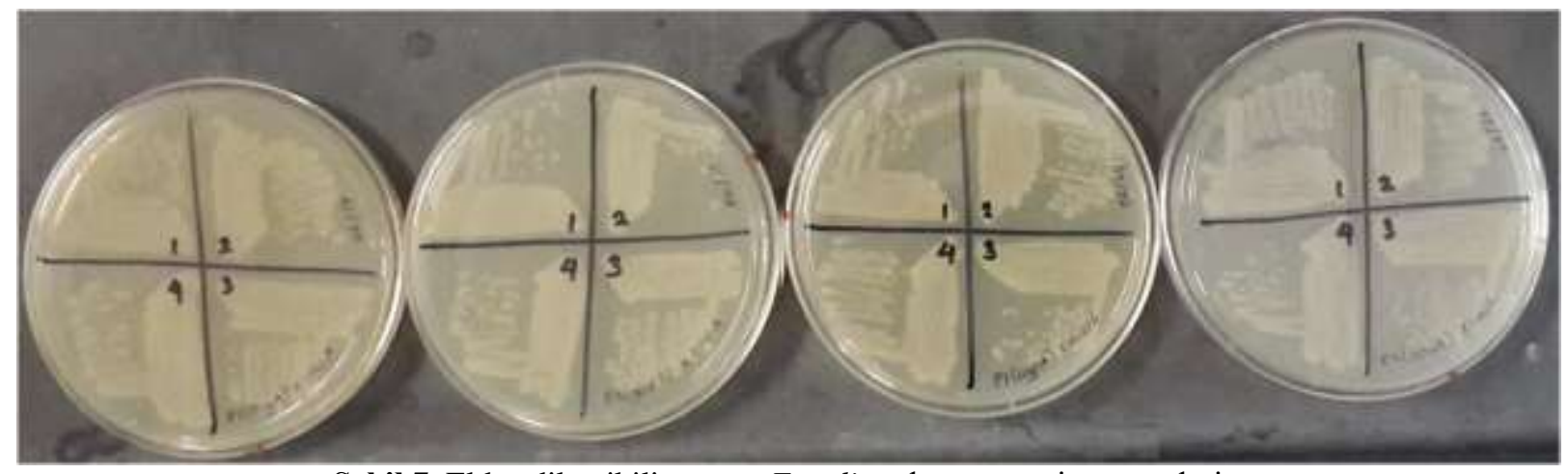

Şekil 7. Elde edilen ikili mutant $E$. coli suşlarının petri görüntüleri

\section{Sonuç ve Öneriler}

Yapılan çalışma sonucunda P1 fajı kullanılarak seçilen E. coli suşlarından diğer suşlara kanamisin gen kasedi ile oluşturulan mutasyonlar taşınmıştır ve böylelikle iki gen bakımından mutasyona uğramış olan yeni suşlar, "ikili (double) mutantlar" elde edilmiştir. Bu çalışmada seçilen E.coli suşlarından alıcı suşlara tsgA, yhdT, ugpA, aroG gen mutasyonları taşınmıştır. Bu teknik kullanılarak iki E.coli suşlar arasında mutasyonlar taşınabilir ve birçok gen bakımından mutasyona uğramış yeni suşlar elde edilebilir. Bu sayede bakterilere sahip olmadıkları özellikler, yetenekler kazandırılabilir ya da kaybettirilebilir.

\section{Teşekkür}

Bu çalışma 114Z987 nolu Tübitak projesi tarafindan desteklenmiştir. Ayrıca KEIO koleksiyonunu temin eden National Bio Resource Project Japan (NBRP) ve laboratuarımızdaki P1 deneysel alt yapısının kurulmasındaki değerli katkılarından dolayı sayın Prof. Dr. Tim Larson'a teşekkür ederiz. Muğla SK Üniversitesi Bilimsel Araştırma Projeleri koordinatörlügüne de teşekkür ederiz. 


\section{Yazarların Katkısı}

$\mathrm{Bu}$ makalede, veri toplama ve işlemesi, analiz/verilerin yorumlanması ve makale bölümlerinin yazılması, bütün yazarlar arasında belirli görev dağılımları ile gerçekleştirilmiştir.

\section{Çıkar Çatışması Beyanı}

Yazarlar arasında herhangi bir çıkar çatışması bulunmamaktadır.

\section{Etik Kurul Beyanı}

Yapılan çalışmada, araştırma ve yayın etiğine uyulmuştur. Bu çalışmada etik kurul izni gerekmemektedir.

\section{Kaynaklar}

[1] Baba T., Ara T., Hasegawa M., Takai Y., Okumura Y., Baba M., Datsenko KA., Tomita M., Wanner B.L., Mori H. 2006. Construction of Escherichia coli K-12 in-frame, single-gene knockout mutants: the Keio collection. Molecular Systems Biology, 2 (1): 1-11.

[2] Bertani G. 1951. Studies on lysogenesis. The mode of phage liberation by lysogenic Escherichia coli. JBacteriol. Sep, 62 (3): 293-300.

[3] BrammarWJ. 2001. Specialized Transduction. Encyclopedia of Genetics, 1858-1860.

[4] Cherepanov PP., Wackernagel W. 1995. Gene disruption in Escherichia coli: TcR and KmR cassettes with the option of Flp-catalyzed excision of the antibiotic-resistance determinant. Gene, 158: 9-14.

[5] Datsenko KA., Wanner BL. 2000. One-step inactivation of chromosomal genes in Escherichia coli K-12 using PCR products. Proc Natl Acad Sci. 6, 97 (12): 6640-6645.

[6] Lennox ES. 1955.Transduction of linked genetic characters of the host by bacteriophage P1. Virology, 1:190-206.

[7] Lobock BM., Rose DJ., Plunkett G., Rusin M., Samojedny A., Lehnherr H., Yarmolinsky MB., Blattner FR. 2004. Genome of Bacteriophage P1. Journal of Bacteriology, 186 (21):7032-7068.

[8] Silhavy T.J., Berman ML., Enquist L.W. 1984. Experiments with gene fusions. Cold Spring Harbor Laboratory, Trends in genetics. Trends in Genetics, 1: 61.

[9] Snyder L., Champness W. 2007. Molecular genetics of bacteria. American Society for Microbiology, Washington, DC, USA, $3^{\text {rd }}$ ed., 293-337.

[10] Thomason L.C., Costantino N., Court D.L. 2014. E. coli Genome Manipulation by P1 Transduction. Current protocols in molecular biology. 79 (1): 1.17.1-1.17.8.

[11] Yarmolinsky M.B., Sternberg N. 1988. Bacteriophage P1. The Bacteriophages, 1: 291-438

[12] Zhu X.D., Sadowski P.D. 1995. Cleavage-dependent Ligation by the FLP Recombinase. Characterization of a mutant flp protein with an alteration in a catalytic amino acid. Journal of Biological Chemistry, 270 (39): 23044-23054.

[13] Zinder N.D. 1992. Forty years ago: the discovery of bacterial transduction. Genetics, 132: 291294.

[14] Zinder N.D., Lederberg J. 1952. Genetic exchange in Salmonella. J. Bacteriol., 64:679-699. 